\title{
O Intervalo Descompassado entre a vigência e a efetividade da norma - A (Re)emergência da questão ressocializadora ${ }^{1}$
}

\author{
Fostering the validity and the effectiveness of law \\ - the (re)emergence of the rehabilitation issue
}

INÊS FARINHA

inesimoesf@gmail.com

GALILEU - REVISTA DE DIREITO E ECONOMIA - e-ISSN 2184-1845

Volume XXI $\cdot 1^{\text {st }}$ January Janeiro $-30^{\text {TH }}$ June Junho $2020 \cdot$ pp. 142-158

DOI: http://doi.org/10.26619/2184-1845.XXI.1.6

Submitted on March $23^{\text {th }}, 2020 \cdot$ Accepted on June $4^{\text {th }}, 2020$

Submetido em 23 de Março, 2020 . Aceite a 4 de junho, 2020

RESUMO Os polos dinamizadores da execução da pena de prisão, que encontram na proteção de bens jurídicos e na reintegração do agente na sociedade o seu expoente máximo, continuam a ser a pedra angular do sistema penal. Contudo se o legislador se mostra fiel ao ideário ressocializador, por outro lado, o paulatino desajustamento da cena carcerária desvirtua a ratio essendi da aplicação da pena privativa da liberdade. A crescente taxa de encarceramento que se tem verificado nos últimos anos aliada à replicação da deviance criminógena no espaço carcerário, especialmente em Portugal, faz com que grassem vozes a favor do desencarceramento, dando primazia a penas não privativas da liberdade. Da sintomatologia registada, e positivada em relatórios e estudos internacionais e internos, verifica-se uma "síndrome de decalque", dado que os muros não conseguem filtrar os fenómenos desviantes, ou, pelo menos, não têm almejado tal desiderato. É na especial atenção ao cidadão privado da sua liberdade que se encontra o ponto ótimo de análise para justificar a secundarização que tem vindo a ser dada à reintegração do indivíduo na sociedade.

1 O presente trabalho foi elaborado no âmbito da unidade curricular do $1 .^{\circ}$ semestre do Curso de Doutoramento em Direito na Universidade Autónoma "Direito: da norma ao procedimento e à fase aplicativa", lecionada pelo Professor Doutor Manuel Monteiro Guedes Valente, a quem muito agradecemos os contributos académicos e devemos os ensinamentos e, bem assim, os comentários críticos aquando da exposição oral do presente tema em aula. 
O Intervalo Descompassado entre a vigência e a efetividade da norma- A (Re)emergência da questão ressocializadora INÊS FARINHA

GALILEU - e-ISSN 2184-1845 - Volume XXI - Issue Fascículo $1 \cdot 1^{\text {st }}$ January Janeiro $-30^{\text {th }}$ June Junho 2020 - pp. 142-158

PalaVRas-chave Sistema Punitivo, Prisão, Vigência, Eficácia, Reintegração, Tratamento, Reincidência.

ABSTRACT The dynamic poles underlying the prison sentence enforcement, which find in the legal assets protection and rehabilitation of the incarcerated its maximum expression, are still the heart and soul of the penal system. However, if the legislator stands faithfully committed to the principle of rehabilitation, on the other hand the gradual inadequacies indoors distort the "ratio essendi" of the prison sentence enforcement. The incarceration rate increase observed over the past few years and the the growing massification of criminal deviance inside the prison walls, especially in Portugal, has led some enthusiastics to believe in the "power of release" rather than the opposite, giving way to the non-custodial sentences. Analysing the symptoms derived from international and domestic reports and studies, one may recognise "a tracing syndrome" only illustrated by the total incapacity of the prison walls to filter deviant phenomena. Focusing on the secluded men is the best starting point to justify the lack of attention given in the field of reintegration back in the society.

KEYWORDS Punitive System, Prison, Validity, Effectiveness, Reintegration, Treatment, Recidivism.

\section{Da atualidade do tema - notas introdutórias}

Os fins das penas, no seio do estudo do direito penal substantivo puro sempre se mostrou uma matéria votada a constante metamorfose.

À semelhança daquilo que BECCARIA já idealizava há mais de dois séculos atrás, a finalidade da pena convoca e provoca, em pleno século XXI, novos olhares e sobretudo exige uma profunda reflexão que ultrapassa a mera ratio legis de tal finalidade.

Face à corrente securitária que tem perpassado o direito penal, e mais ainda, diga-se, naquele que é o seu epílogo - o da execução da pena - mostra-se vital aproximar os polos dinamizadores que constituem a execução.

Pelo que, se por um lado se visa a proteção de bens jurídicos - prevenção geral - e a manutenção da paz social, por outro lado, e, concomitantemente, pretende-se exaltar no homem agrilhoado a sua remição, para que não regresse ao mundo do crime.

É precisamente aqui que tentaremos demonstrar a contradição em que se vê embrenhado o artigo $40 .^{\circ}$, n. $^{\circ} 1$ do Código Penal. 
Se de uma banda o legislador se mostra fiel ao ideário ressocializador, promovendo uma maior atuação sobre o espírito e menos sobre o corpo ${ }^{2}$, o que se repercute no acervo legislativo de execução de penas português no seu todo, de outra banda, o paulatino desajustamento da cena carcerária desvirtua a ratio essendi da aplicação da pena privativa da liberdade.

O fenómeno penitenciário, como o ponto de chegada - e simultaneamente como ponto de partida - do iter (processual) penal do cidadão delinquente, deve, como bem salienta ANABELA MiRANDA RoDRIGUES ${ }^{3}$, "privilegiar a eficácia e concorrer para a rentabilidade da justiça, procurando evitar ou atenuar a estigmatização dos reclusos - impedir a dessocialização e promover a não-dessocialização".

O drama do homem recluído, muitas vezes secundarizado pelo sistema, encontra-se agonizado na anomia organizada de uma estrutura em confronto consigo mesma, repercutida nas crescentes tensões que abalam o desiderato ressocializador.

A crescente taxa de encarceramento que se tem verificado nos últimos anos aliada à replicação da deviance criminógena no espaço carcerário, especialmente em Portugal, faz com que grassem vozes a favor do desencarceramento, dando primazia a penas não privativas da liberdade.

O intervalo descompassado que neste ensaio se pretende afinar, visará (tanto quanto nos for possível) encurtar o caminho entre a postulação da vigência da norma e a efetividade da mesma, reverberada no modelo ressocializador.

Cientes de que há (ainda) um longo caminho a percorrer para a plena e efetiva reconstrução do fim último ínsito aos fins das penas, concluímos, na esteira de ZAFFARONI, que "a prevenção especial de ressocialização é o único fim das penas admissível num Estado de Direito democrático e social"4.

\section{Uma brevíssima aproximação ao problema ou uma leitura kelsiana do artigo 40. ${ }^{\circ}$ do Código Penal}

A vigência, como a definiu HANS KeLsEN 5 , é a existência específica de uma norma. Reconduzindo-se à ideia de validade, o que por sua vez se projeta naquilo a que aquele autor caracteriza

\footnotetext{
2 Acompanhamos aqui o que nos ensina Beccaria sobre os fins das penas. BECCARIA, Cesare - Dos Delitos e das Penas. 2. ${ }^{a}$ Edição. Tradução do italiano Dei Delliti e delle Pene de José de Faria Costa. Lisboa: Fundação Calouste Gulbenkian, 2007, p. 85 .

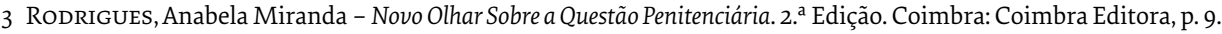

4 Zaffaroni, Eugenio Raúl - Tratado de Derecho Penal. Parte General- Tomo I. Buenos Aires: Ediar, 1998, pp. 70-72.

5 Nas palavras de Hans Kelsen, "com a palavra "vigência” designamos a existência específica de uma norma. (...) Se designamos a existência específica de uma norma como a sua vigência, damos desta forma expressão à maneira particular pela qual a norma - diferentemente do ser dos factos naturais - nos é dada ou se nos apresenta. In
} 
por "dever-ser"6, uma norma tem de conter em si mesma um referente superior que a legitima e a densifica para que possa ser exigida como válida?.

Neste sentido como bem referencia José RAMOs", "a necessidade de cada norma estar fundada na existência de outra norma de grau - necessariamente - superior que a autoriza e lhe confere legitimidade, importa que o sistema normativo corresponda a uma estrutura encadeada de comandos sucessivos, na qual cada norma de grau superior autoriza a norma inferior", rectius, a norma fundamental, a qual é, diz o mesmo autor "fundamento da obrigatoriedade de cumprimento das normas constitucionais".

O que, levado ao extremo, quererá dizer que a conduta que se extrai do ato normativo deve ser considerada obrigatória "não apenas do ponto de vista do indivíduo que põe o ato, mas também de um ponto de vista de um terceiro desinteressado" ${ }^{\text {, }}$ que se nivelará por uma norma de valor superior ${ }^{10}$.

Donde, para afirmarmos que uma norma é válida, e, portanto, vigente, deverá ter um mínimo de eficácia ${ }^{11}$. Como já referimos, para Kelsen, a validade (ou a vigência) de uma norma "consiste na existência da norma jurídica, ou seja, em sua entrada regular dentro de um sistema jurídico"12.

Se atentarmos no teor do artigo $40 .^{\circ}$, n. $^{\circ} 1$ do Código Penal ${ }^{13}$, verificamos que o seu escopo é o de estipular as finalidades das penas. Por um lado, reconhecendo que da sua aplicação se protegerão bens jurídicos, e que, por outro, se visará a reintegração do agente na sociedade.

Kelsen, Hans - Teoria Pura do Direito. 6. Edição. Tradução de João Batista Machado. São Paulo: Martins Fontes, 1998, p. 7 .

6 Kelsen, Hans - Teoria Pura..., p. 7.

7 Estamos aqui a referir-nos ao que Kelsen concetualiza como norma fundamental - Grundnorm - a qual é o fundamento da obrigatoriedade de cumprimento das normas constitucionais e, por essa via, legitima todas as normas integradas no sistema. Vide RAMOS, José Joaquim Monteiro - «A dupla perspetiva da norma fundamental em Hans Kelsen». In: Politeia - Estudos Comemorativos dos 30 Anos do Instituto Superior de Ciências Policiais e Segurança Interna e dos 10 anos da Politeia, Volume I, Studia Varia, Ano X-XI-XII, 2013-2014-2015, p. 221.

8 RAMOS, José Joaquim Monteiro - «A dupla perspetiva...», p. 219.

9 Kelsen, Hans - Teoria Pura..., p. 6.

$10 \mathrm{O}$ que, no caso português, encontra albergue constitucional por via do artigo $30 .^{\circ}, \mathrm{n} .^{\circ} 5$ da Constituição da República Portuguesa, uma vez, como refere: "Os condenados a quem sejam aplicadas pena ou medida se segurança privativas da liberdade mantêm a titularidade dos direitos fundamentais (...)".

11 Para Kelsen - Teoria Pura..., p. 8: “Uma norma jurídica é considerada como objetivamente válida apenas quando a conduta humana que ela regula lhe corresponde efetivamente, pelo menos numa certa medida. Uma norma que nunca e em parte alguma é aplicada e respeitada, isto é, uma norma que - como costuma dizer-se - não é eficaz em uma certa medida, não será considerada como norma válida (vigente)".

12 BitTAR, Eduardo - «A Justiça Kelsiana». In: Revista da Faculdade de Direito da Universidade de São Paulo, 96, p. $544-545$.

$13 \mathrm{O}$ artigo $40^{\circ},{ }^{\circ} .^{\circ} 1$ do $\mathrm{CP}$ refere o seguinte: "A aplicação de penas e de medidas de segurança visa a proteção de bens jurídicos e a reintegração do agente na sociedade". 
Diríamos assim que, para o artigo $40 .^{\circ}$, n. ${ }^{\circ} 1$ do $\mathrm{CP}$ se considerar válido, mormente no que se refere à reintegração do agente na sociedade, terá de existir uma refração mínima entre aquilo que prescreve e o fim a que se devota no plano da execução.

O que necessariamente quer dizer que a projeção do postulado na norma deverá encontrar pleno correspondente no campo da eficácia, in casu, ser atingida a vocação de reintegração do agente que cometeu um crime, para que não volte a cometer crimes no futuro.

É precisamente aqui que se situa o ponto nevrálgico da discussão.

Então, se uma norma não é eficaz (em certa medida), quer dizer que não pode considerar-se válida. Há assim uma propensão, da norma (ainda que ténue), para se esgotar no plano da sua eficácia. O que faz com que tendam a existir duas realidades que se conexionam e se relacionam complementarmente.

Como veremos não é inteiramente o que acontece no caso do artigo $40 .^{\circ}, \mathrm{n} . .^{\circ} 1$, mas podemos afirmar que em certa medida o é. E vejamos porquê.

Do ponto de vista do dever ser, a eficácia do sistema prisional apenas se verificaria se o postulado do ideário ressocializador ou reintegrador lograsse uma plena efetivação, ou seja, que através da aplicação da pena o agente interiorizasse o valor dos bens jurídico-penais violados com a prática do crime.

Como bem ressalva NuNO CAIADO ${ }^{14}$, "a execução das penas deveria ser o mais importante pilar da política criminal, pois é nele que convergem, de modo pleno, as grandes finalidades do processo penal". Porém, como se tem verificado, a execução das penas tem sido pouco valorizada e parcos investimentos têm sido feitos do ponto de vista financeiro e doutrinal, muito por conta das características que modelam todo um sistema completamente apartado do seu fim.

A privação da liberdade de um qualquer indivíduo é a ultima ratio do sistema punitivo, que deve centrar-se na construção "do homem novo", com vista a reintroduzi-lo mais tarde de novo na sociedade, apto a dirigir a sua vida sem a prática de crimes. Assim, pode falar-se de uma finalidade de prevenção da reincidência ${ }^{15}$.

14 CAIAdo, Nuno - «A Política Criminal para a execução das penas e medidas uma ideia para uma década». In: Revista Julgar, n. ${ }^{\circ} 28,2016$.

15 No preâmbulo do C.P. de 1995 (alterado pelo Decreto-Lei n. ${ }^{\circ}$ 48/95, de 15 de Março) pode ler-se a este propósito o seguinte: "A realização dos ideais de humanidade, bem como a reinserção social assinalados, passam hoje, indiscutivelmente, pela assunção do recluso como sujeito de direitos ou sujeito de execução, que o princípio do respeito pela sua dignidade humana aponta de forma imediata. (...) Assinala-se, portanto, um decisivo movimento de respeito pela pessoa do recluso que, reconhecendo, a sua autonomia e dimensão como ser humano, assaca à sua participação na execução um relevantíssimo papel na obra de inserção social, em que não só a sociedade como também o recluso são os primeiros interessados" 


\section{O Desiderato da (Re)socialização - uma questão nova ou uma velha questão?}

O ideário da ressocialização não é de todo uma questão hodierna. É, como veremos, uma verdadeira doutrina com plena aplicação, pelo menos, em Portugal, desde o Código Penal de 1982 e que continua a modelar a forma como olhamos todo um sistema que se esgota e se remodela nesta mesma base.

Concordamos que tal modelo, e dizemo-lo com MARC ANCEL ${ }^{16}$, "não trata de defender a sociedade contra os delinquentes porque são perigosos, mas de defender estes, porque estão em perigo, socializando-os".

O fim ínsito à prevenção especial, é o de que, havendo um desvio aos cânones valorativos comunitários, aquando da prática do crime, se isole o indivíduo do meio em que "socializa", do "caos" societário a que está exposto, confinando-o a um outro meio ambiente onde reaprenderá, querendo, a adquirir tais cânones, para ser, in fine, "devolvido" à sociedade, como ser (re)socializado.

E reafirmamos esta voluntas ${ }^{17}$, porque precisamente, depende de uma adesão livre do sujeito recluído. De tal sorte que, se não quiser aderir à sua própria ressocialização, o indivíduo não é obrigado. E mesmo, a não aplicação do efeito catalisador da ressocialização não pode desvirtuar o que se envida com a aplicação de uma pena de prisão.

Donde, é precisamente a forma como este mesmo mecanismo é, ou está a ser modelado, que aqui pretendemos colocar em crise, porque, como veremos está profunda e inapelavelmente em crise. Mas aqui voltaremos oportunamente.

Até agora, podemos afirmar que o sistema de execução de penas tem vindo a fazer um caminho de melhoramento, sob o timbre que desde o século XIX, vem consolidando toda a sua prática - o da recuperação do delinquente ${ }^{18}$.

Contudo, nem sempre assim foi. Desde meados do século XX que a ressocialização foi colocada em crise e há vários autores ${ }^{19}$ que nos meados daquele século já vinham apontando uma certa descrença no modelo de encarceramento institucionalizado. Isto porque

16 Ancel, Marc - A nova defesa social. Tradução Osvaldo Melo. Rio de Janeiro: Forense, 1979.

17 Como não deixa de registar Anabela Rodrigues, o princípio do tratamento voluntário "é um princípio que não pode deixar de se fazer valer, dado o perigo que para os direitos fundamentais do recluso representa a imposição de um tratamento coativo. (...) O "direito a não ser tratado" é parte integrante do "direito de ser diferente" que não pode ser posto em causa nas sociedades pluralistas e democráticas do nosso entorno cultural" [Novo Olhar...,

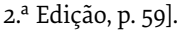

18 A título esparso podemos dizer que a posição do recluso provoca, desde logo, o dever de assegurar um núcleo de direitos que lhe não podem ser assacados por razões ligadas à execução. Por isso a previsão de uma esfera de direitos e de garantias é a base fortificada do caminho para a ressocialização.

19 Referimo-nos aqui a Moritz Liepmann e Max Grünhut, citados por LeITE, André Lamas - «Ressocializar, hoje? Entre o "mito" e realidade». In: Revista do Ministério Público, 156, dezembro de 2018. 
face às elevadas taxas de criminalidade, não se lograva alcançar uma proporcional descida da reincidência.

A adensar a este estado de coisas, o artigo de MARTINSON "What Works - Questions and anwers about prison reform" ${ }^{20}$, veio colocar em perspetiva o modelo ressocializador, defendendo que os programas desenvolvidos em meio prisional não logravam demonstrar a eficácia dos métodos de "tratamento" aplicados aos reclusos, acabando por concluir essencialmente que os programas de educação eram incipientes, as terapias não eram aplicadas com competência e a supervisão e aconselhamento prestados aos reclusos não era suficiente, afirmando mesmo que não existia um "full-hearted commitment to the strategy of treatment"

Todavia, se a teoria do "nothing works" marcaria um período histórico com maior impacto nos EUA, a verdade é que tal estudo não abandonava in totum uma visão reabilitadora, que poderia ter resultados positivos na diminuição da reincidência.

A questão, volvidos mais de quarenta anos, situa-se precisamente, na densificação da matriz ressocializadora do sistema prisional português, e, essencialmente, para onde caminha.

Neste sentido podemos afirmar que a ressocialização se encontra num impasse, digladiando-se entre a sua função garantística ${ }^{22}$, seu propósito, e a nova demanda securitária que define comportamentos e exige a eficácia do sistema punitivo.

A fase de execução não se pode mostrar arredada daquilo que são os novos fenómenos e formas de delinquir. O surgimento da sociedade do medo, de permanente vigilância, do futuro incerto inaugurou aquilo que já antes na obra Leviatã havia sido propugnado de que "cada homem é inimigo de cada homem"23.

E nós, somos forçados a perguntar. E as prisões, neste novo binómio segurança-garantismo, em que posição as deixamos? Estaremos novamente diante de uma apregoada e irreversível crise ressocializadora, incapaz de se reencontrar com o seu fim último?

$\mathrm{Na}$ sua profunda força propulsora, o crime traveste-se e dissimula as suas fronteiras. A par das formas de criminalidade a que chamaremos de "doméstica", somos invadidos pelo

20 A publicação desta obra corresponde a um estudo levado a cabo por Martinson e a sua equipa, em 1966, para o The New York State Governor's Special Committee on Criminal Offenders para aferir da necessidade do escopo reabilitativo das prisões de Nova Iorque.

21 A tradução mais fiel será "dedicação total à estratégia de tratamento".

22 Esta função garantística, é nas palavras de Anabela Rodrigues, um "dever que ao Estado incumbe - e que entronca na sua vertente social - de ajuda e de solidariedade para com os membros da comunidade que se encontrem em especial estado de necessidade, como é o caso do recluso" [Novo Olhar..., 2. ${ }^{a}$ Edição, p. 188].

23 VAlente, Manuel Monteiro Guedes - Direito Penal do Inimigo e o Terrorismo: O «progresso ao retrocesso». 2. ${ }^{\text {a }}$ Edição, Coimbra: Almedina, p. 51 e ss. Para Thomas Hobbes, autor da obra "Leviatã", "são inimigos os seres humanos que estão no estado natureza, produtor de constante perigo e ameaça à existência humana (...), o que levou Hobbes a pensar o Direito Penal para os cidadãos maus e outro Direito Penal para os inimigos". 
crime transnacional, pelas complexas estruturas que o sustentam e pela alucinada cumplicidade do etéreo espaço cibernético, que fornece as vias (ainda mais) rápidas para a sua consumação.

Ora como veremos, tal como antevira MARTINSON, em parte, há uma consabida distância entre a boa intencionalidade da lei e os efeitos práticos que o encarceramento deverá necessariamente produzir no afastamento da reincidência.

Este intervalo descompassado entre realidades, a do crime e a da execução da pena, faz com que a necessidade de combater a primeira, esbarre na ineficácia da segunda. Problemas velhos e realidades novas, fazem do conceito de ressocialização, um problema novo que deve ser reajustado à voracidade e transmutação dos fenómenos criminais hodiernos.

\section{O intervalo descompassado entre a vigência e a efetividade - a (re)colocação do problema}

A população carcerária portuguesa, de acordo com os dados mais recentes ${ }^{24}$, era de 13.440 reclusos no ano de 2017, dos quais 275 inimputáveis. O número de preventivos era de 2.105 e o de condenados fixava-se em 11.335, sendo que cerca de $93,6 \%$ era do sexo masculino e $6,4 \%$ do sexo feminino.

Ainda que o número total de reclusos tenha diminuído cerca de 339 reclusos $^{25}$, a verdade é que continua a existir sobrepopulação carcerária. Para se ter uma ideia mais real, no ano de 2016 o número de reclusos por cada 100.000 habitantes era de 133, quando idealmente deveria ser de $100^{26}$.

O excesso de cidadãos encarcerados dita a falência do sistema, sob vários prismas. Se um lado, persistem problemas a montante, designadamente no próprio sistema punitivo que não deveria estar a encarcerar tanto, por outro lado eles desaguam inevitavelmente a jusante, dentro dos muros da prisão.

Concordar-se-á que o parque prisional se encontra hoje obsoleto face à demanda ressocializadora, chegando ao que podemos apelidar do paradoxo ressocializador (ou, se quisermos ressocialização invertida), tão afastado de si próprio. A degradação dos espaços prisionais, mercê do parco investimento nesses mesmos espaços, é a base da problemática. Se para o homem recluído o fardo da "deportação" para um espaço, onde obrigatoriamente irá

24 Informação retirada do Relatório Anual de Segurança Interna, págs. 131 e ss.

25 Idem.

26 BoAVIDA, Joaquim - A Flexibilização da Prisão. Coimbra: Almedina, 2018, p. 261. Este fenómeno, como denota o autor tem-se vindo a agravar desde 2013 , com uma média de entrada de sensivelmente 100 reclusos/ano. Nos anos de 2007/2008 verificou-se um decréscimo de cidadãos encarcerados fruto das alterações aos códigos penal e de processo penal. 
estar confinado por certo período, já é, de per si, estigmatizante, a ruína desse espaço comportará e transportará para o indivíduo uma sensação de inerente destruição.

Como bem aponta JOAQUIM BOAVIDA, "sem edifícios apropriados e com uma lotação que seja adequada para s respetivas funções, todo o esforço das pessoas que intervêm na execução das penas será fragmentário"27.

À questão da deterioração física dos edifícios, alia-se a questão da "contaminação do espaço prisional". Quer isto dizer que nos mesmos espaços comuns convivem reclusos primários, condenados por crimes menos graves ou mais graves, reclusos tendencialmente mais geradores de distúrbios, ou outros com melhores perspetivas de reintegração.

Todo este melting pot $^{28}$ carcerário é amplamente potenciador de ambientes propensos a gerar situações de tensão, fomentando a criação interna de tendências desviantes. Algo que não é inteiramente uma inverdade.

Em 2017, o Corpo de Guarda Prisional procedeu à apreensão de diverso produto estupefaciente, aumentando cerca de $92 \%$ no haxixe e $36 \%$ na cocaína. Por outro lado, a apreensão de armas brancas e telemóveis aumentou respetivamente $19,7 \%$ e 6,4\% respetivamente ${ }^{29}$.

Já mais recentemente, foi alegadamente detetado o contrabando de produto estupefaciente e outros objetos, como baterias e telemóveis, para dentro do Estabelecimento Prisional de Vale de Judeus através do uso de drones ${ }^{30}$, ou ainda também o uso de telemóveis para veicular para o exterior imagens do interior do E.P. de Paços de Ferreira ${ }^{31}$.

Ora, estes acontecimentos devem ser lidos como uma expressão da desadequação do meio prisional face ao que se pretende que ele produza sobre o homem recluído, ou seja, fornecer-lhe os meios adequados, garantindo a criação de oportunidades para a jornada de preparação para além dos muros que se inicia com o cumprimento da pena privativa da liberdade.

Tudo isto diríamos nós, coadjuvado por um outro problema trespassa não só o sistema prisional, mas, enfim, todo o sistema de justiça. A insuficiência ou a deficitária alocação de recursos financeiros. Questão que afeta recursos humanos, instalações físicas, programas de reabilitação, et ceterae.

27 BoAVIDA, Joaquim - A Flexibilização..., p. 264.

28 Numa tradução mais corrente significa "caldo de culturas".

29 Relatório Anual de Segurança Interna, p. 134.

30 In Observador, "Presos recebem contrabando por drones", publicado a 27.02.2019, https://observador.pt/2019/02/27/ presos-recebem-contrabando-por-drones/.

31 In Jornal de Notícias, "Festa de arromba de presos na cadeia filmada com telemóveis", publicada a 10.02.2019, https:// www.jn.pt/justica/videos/interior/festa-de-arromba-de-presos-na-cadeia-filmada-com-telemoveis-10562686. html. 
Não digamos, porém, que nenhum investimento tenha sido feito, continuando a ser uma preocupação dos governos. Aliás, na Estratégia Plurianual de Requalificação e Modernização do Sistema de Execução de Penas e Medidas Tutelares Educativas 2017/202732, constata-se essa mesma preocupação de requalificação das estruturas, da recomposição dos recursos humanos, da valorização da oferta educativa à população reclusa, dando-se mesmo enfoque à "eliminação do fosso que separa o direito legislado da sua aplicação efetiva" 33 .

A contrastar com a boa intenção das estratégias e de alguns progressos assinalados, o Comité para a Prevenção da Tortura e das Penas ou Tratamentos Desumanos e Degradantes, na sua mais recente visita aos estabelecimentos prisionais portugueses, em 2016, apontou a questão da sobrelotação bem como as condições degradantes e desumanas dos estabelecimentos prisionais de Caxias, Lisboa Central e Setúbal ${ }^{34}$.

E é aqui precisamente que o sistema se aparta daquilo a que se projeta.

A ressocialização deve almejar uma solução eficaz que coloque em marcha um plano que acompanhe o sujeito condenado à reclusão. Isso significa, na esteira de ALBIN ESER ${ }^{35}$, "a colocação dos meios adequados ao serviço do agente do crime para que o mesmo não reincida".

Efetivamente, pode-se constatar que no que aos programas de educação, formação profissional e atividade laboral diz respeito, os números têm sido evidência do investimento que tem sido feito, com uma melhoria a partir do ano de 2012 até 2016, com a percentagem de reclusos inativos a passar de $49,5 \%$ para $27,2 \%$, os reclusos em formação escolar de $12,6 \%$ para $23,7 \%$ e em formação profissional de $3,7 \%$ para $6,6 \%{ }^{36}$.

Concordamos e defendemos que tais programas são efetivamente um caminho, podendo fazer renascer no recluso competências que não se encontravam adquiridas ou fazendo emergir outras que não exatamente as relacionadas com o exercício diário da atividade laboral.

32 Consultar: "Olhar o Futuro para Guiar a Ação Presente - Relatório sobre o Sistema Prisional e Tutelar", Setembro de 2017", disponível em https://www.portugal.gov.pt/download-ficheiros/ficheiro.aspx?v=29dd78f7-do76-4d8oaogb-6b2c94ecogd5.

33 Consultar: "Olhar o Futuro...", p. 11.

34 Tal como se refere no Relatório daquele Comité acerca da visita a Portugal que ocorreu entre 27 de setembro e 7 de outubro de 2016, as situações dos estabelecimentos prisionais de Setúbal e Caxias eram bastantes preocupantes quando se refere: "The conditions for certain vulnerable prisoners at both Caxias and Setúbal Prisons were particular poor, with less than $3 \mathrm{~m} 2$ of living space per prisoner and inmates confined to their cells for up to 23 hours per day. The authorities are urged to provide all prisoners with a minimum of $4 \mathrm{~m} 2$ of living space in multiple-occupancy cells and urgently to renovate the above-mentioned deficiencies." Disponivel em https://rm.coe.int/168078eic8.

35 Eser, Albin - Resozialisierung in der Krise?, citados por LeITE, André Lamas - «Ressocializar, hoje? ...». In: Revista do Ministério Público, p. 92.

36 BoAvidA, Joaquim - A Flexibilização..., p. 277. 
Todavia, estudos há que sugerem "haver bloqueios a que o ensino e a formação profissional sejam efetivamente considerados como vetores importantes na reinserção social do recluso, denunciando que em muitos casos (...) serão apenas uma forma de ocupação durante o período de reclusão havendo por isso (...) uma taxa de sucesso ainda reduzida"37.

\section{Um Direito à (Res)Socialização}

Ao longo dos tempos muitos conceitos têm sido trazidos para o campo do direito penitenciário, modelando a lei escrita, conforme razões de política criminal têm vindo a ditar.

Destarte, o conceito de "reintegração" do indivíduo dá azo à multiplicação de outros conceitos que, não raramente aludem a fins distintos, mas que podem induzir a uma certa desorientação que colide com aquilo que pretende ser a verdadeira prevenção especial positiva.

Ressocialização, tratamento ou reinserção do recluso são conceitos que convivem no mesmo espaço de atuação, e não só na lei, indiciando uma sinonímia que pode gerar equí$\operatorname{vocos}^{38}$, porque precisamente se situam em diferentes estádios da execução da pena. Não queremos com isto dizer que os mesmos não tenham validade, até porque os vamos encontrar positivados na lei de execução de penas e os mesmos acabam por ter refração no continuum de execução.

Apesar de na Lei n. ${ }^{0}$ 115/2009, de 12 de outubro, não encontrarmos previsto o termo "ressocialização", o diploma começa no seu artigo $2 .^{\circ}$ por referir que a execução das penas e medidas de segurança privativas da liberdade visa a reintegração do agente na sociedade, falando no artigo $3 .^{\circ}, \mathrm{n}^{\circ} 6$, em tratamento prisional e reinserção social, através do ensino, formação, trabalho e programas.

37 Gomes, Conceição, DuARte, Madalena e Almeida, Jorge - «Crimes, Penas e Reinserção Social: um olhar sobre o caso português». In: Atas dos Ateliers do V Congresso Português de Sociologia, Sociedades Contemporâneas: Reflexividade e Ação, Atelier: Direito, Crimes e Dependências, disponível em https://aps.pt/wp-content/uploads/2017/08/ DPR4628adea6692c_1.pdf. Estes autores apontam ainda uma outra questão que decorre da "discrepância verificada entre a formação ministrada e a oferta do mercado de trabalho. De facto, as entrevistas realizadas evidenciaram a ausência de uma estratégia de enquadramento da formação profissional dos reclusos, no sentido de lhes criar competências e de os adaptar às necessidades do mercado de trabalho actual. Predominam, há vários anos, as actividades de mecânica, serralharia, cestaria, sapataria, encadernação, tapeçaria, horticultura, polimento e marcenaria. Com excepção da informática, a formação, em geral, não se abriu a novas áreas, embora existam estabelecimentos prisionais que têm "uma dinâmica diferente". Para além disso, nem sempre se atende à identificação de carências e de necessidades especiais dos próprios reclusos, individualmente considerados".

38 MARTINSON apud LeITe, André Lamas - «Ressocializar, hoje?...». In: RMP, p. 81, descreve os “(...) variados métodos aptos a atingir a reabilitação do recluso: a formação educativa e vocacional nas prisões, as terapias psicológicas individuais e de grupo, (...) o tratamento médico, o sentencing, o cumprimento da pena em meio aberto, a probation e a liberdade condicional, a intensive supervision e o tratamento comunitário." 
O conceito de tratamento prisional tem de nesta sede ser interpretado cum grano salis. O uso da expressão na norma legal está nos antípodas da ideia de "cura", no sentido de intervenção num sujeito doente. Contudo, se lida por referência às medidas de segurança privativas da liberdade, aí, parece-nos fazer mais sentido, atenta a componente de tratamento e intervenção.

Embora a lei coloque em traços gerais os ditames pelos quais se deve modelar todo um sistema de execução, o leit motiv terá sempre de ser a pessoa humana sob a qual assentam os holofotes da sua própria dignitas. O direito à socialização deverá, nestes termos, de ser lido sob diversos prismas.

Primo, deve hoje reconhecer-se a prisão como um espaço homogeneizado e multicultural que exige diferentes tipos de intervenção, numa lógica de multi-level intervention. Quer isto dizer que, por um lado, cada recluso exigirá uma planificação distinta ${ }^{39}$, atendendo ao tipo de crime por que vem condenado, ao período de encarceramento por que vem condenado, ou ao seu estado psicológico, et ceterae.

O que necessariamente traduzirá ao menos que, ultrapassada a relação especial de poder $^{40}$ a que esteve submetido ao longo de (demasiados) anos, o recluso seja um sujeito de direitos de forma plena.

Assim advogamos a posição de que o espaço carcerário mais do que evitar a regressão a um estádio anterior ao da execução, promova efetivamente a não (des)socialização do recluso. E neste sentido, na senda de COSTA ANDRADE ${ }^{41}$, a (res)socialização deverá ser "um direito do recluso" e simultaneamente "uma obrigação para o Estado", o que se encontra espelhado na conjugação dos artigos $2 .^{\circ}$ e $9 .^{\circ}$, al. d) da Constituição da República Portuguesa e que se giza no princípio da socialidade ou solidariedade.

Secundo, é necessário que o Estado, através da instituição penitenciária, forneça o caldo materializador do plano de reintegração do sujeito condenado. Isto equivale a dizer que se terá de buscar o justo termo entre o efeito que se pretende com a pena (que não deixa de ter

39 Aliás essa planificação já existe. O artigo $18 .^{\circ}$ do CEPMPL (Código de Execução de Penas e Medidas Privativas da Liberdade), já prevê a elaboração de um Plano Individual do Recluso, incluindo o plano individual de readaptação e as necessidades de segurança e ordem no estabelecimento.

40 O conceito de relação especial de poder - Besonderes Gewaltverhältnis - conquistou a execução, especialmente no período que se inicia após a II Guerra Mundial. Segundo K. Hesse, não existe uma "relação especial de poder", mas sim "relações especiais diversificadas de sujeição", que consubstanciam um estatuto jurídico especial (Sonderstatus). Apud Anabela Rodrigues, A PosiçÃo JURídica do REClUSO NA EXECUÇÃo DA PENA PRIVATIVA DA LIBERDADE, Instituto Brasileiro de Ciências Criminais, 1999, p. 27.

41 Andrade Costa, Manuel da - «Um (novo) Direito Penal para os (novos) Direitos Fundamentais: Aspectos Éticos das pessoas em situação de doença». In: Actas do V Seminário Nacional de Ética para as Ciências da Vida, Lisboa, 1999 , p. 24. 
na sua essência um caráter puramente retributivo ${ }^{42}$ ) e a humanização que deve ser o motor de combustão do sistema penitenciário globalmente considerado.

Há até quem advogue, como é o caso de GonçALO CORREIA ${ }^{43}$, que o Estado poderá ser responsabilizado pela "violação, por ação ou omissão, de normas ou princípios (...) que desrespeitem regras de ordem técnica ou deveres objetivos de cuidado, resultando na ofensa de direitos ou interesses protegidos."

O que, transposto para a realidade que nos acerca, o Estado seria responsabilizado pela não ressocialização do recluso, isto é, nas palavras daquele autor, "quando o serviço prisional aquando do seu internamento, não tenha garantido a materialização dos meios necessários para a sua integração na sociedade."

Contrariando esta tese André Lamas Leite ${ }^{44}$, refere que "quanto à reinserção do agente na comunidade, o dever do Estado cessa ao colocar ao seu dispor os meios para que ele, querendo, o faça. Se o não fizer, não falhou a tarefa estatal, porquanto consideramos que ela não pode ser levada tão longe. Seria farisaico aceitar-se a inexistência de uma metanoia do condenado e, depois, afirma-se o falhanço da ressocialização quando o condenado a não pretende."

Apesar de sermos partidários desta segunda posição há que indagar: mas o Estado coloca ao dispor do condenado todos os meios, para que, querendo, se reintegre na sociedade?

Neste aspeto cremos que o Estado tem de procurar colocar-se não só um, mas vários passos à frente. Acreditamos que o presente modelo de sistema carcerário existente, ainda fechado sobre si mesmo, não logra conceder ao homem recluído o exercício de forma plena do seu direito à socialização.

Embora existam instituições de solidariedade social ${ }^{45}$ que prossigam o escopo de recuperação e reintegração de ex-reclusos numa fase posterior ao cumprimento da pena, a transição para a liberdade, é, no epílogo da fase de execução da pena, a verificação da efetividade do modelo ressocializador, o que significará que se alcançou, de forma absoluta o ideário preventivo-especial.

42 Bem esgrimido o conceito "retribucionista" atribuído à pena, se se pensar na pena de prestação de trabalho a favor da comunidade, a mesma tem um caráter sancionatório efetivo, isto é, para ser atingido o grau ressocializador na sua plenitude, há primeiro que ser cumprida a pena, no sentido da contraprestação que há-de ser exigível da prática do crime.

43 CorreiA, Gonçalo da Costa Castanho - A Responsabilidade do Estado pelo processo de ressocialização do Recluso. Dissertação de Mestrado - Orientação Científica do Professor Doutor Mário Aroso de Almeida, Porto, maio de 2016, p. 32 e ss.

44 LEITE, André Lamas - «Ressocializar, hoje?...». In: RMP, p. 109.

45 Exemplo de uma dessas instituições é a Associação "O Companheiro" que tem como principal atividade a inserção pessoal, social, laboral e cultural de pessoas que se encontrem em situação de exclusão social, tentando contribuir para a sua inclusão e reintegração societária. Informação disponível em http://www.companheiro. org/historial.html. 
Reconhecer esta complementaridade é também por isso acreditar no poder regenerador que a execução da pena pode ter sobre a persona do indivíduo recluso, nomeadamente fornecendo ferramentas que, de outro modo, não teria, ou pelo menos muito dificilmente, acesso.

Mas a questão coloca-se, porém, a montante, intrinsecamente ligada à relação entre a própria penologia e a prevenção especial positiva. Não sendo nosso ensejo exaurir o tema, contudo indagamos: será que as longas penas de prisão logram atingir o desiderato ressocializador? Quid iuris para as penas mais curtas de prisão?

Mas mais. Haverá tipos de crime com níveis de exigência ressocializadora diferente? Poder-se-á falar em ressocialização a várias "velocidades"?

Reconhecendo que os efeitos da prisonização ${ }^{46}$ serão diferentes em casos de encarceramento mais ou menos longos, eles serão necessariamente diferentes quando se esteja a falar de um condenado por homicídio e de um condenado por corrupção ativa ou por terrorismo.

Se estes são os desafios permanentes que se colocam a este nível, mais de pode aventar que, outros desafios ao sistema prisional e ao seu modelo ressocializador se colocam quando falamos das novas roupagens que o crime enverga.

Que sistemas prisionais necessitamos para ressocializar condenados por criminalidade económico-financeira, associação criminosa, terrorismo, criminalidade altamente organizada?

A tensão criada por todas estas perguntas, e, bem assim a clivagem que o polo securitário e polo ressocializador criam, cada vez mais apartam a realidade vigente da norma da sua correspondente eficácia.

Nas palavras de ANABela Rodrigues"4, "ao direito penal exige-se uma reflexão no sentido tendente a tornar cada vez mais compatível o momento garantístico e o momento funcional do magistério punitivo". Nesta mesma senda, e, cremos, que pela mesma lente argumentativa, podemos afirmar que ao sistema punitivo deveria ser assacada uma visão holística, por forma a enlear dois sistemas que não podem nem se devem excluir mutuamente.

Por um lado, reconhecer que a função judicativa não pode permanecer dissociada da realidade prisional é reconhecer que a dimensão da execução deverá pelo menos produzir um mínimo de evidência que ofereça suporte à fase de determinação da medida da pena.

46 Numa tradução literal do termo "prisonization", retirado do artigo "How prison changes people", disponível em http://www.bbc.com/future/story/20180430-the-unexpected-ways-prison-time-changes-people.

47 Rodrigues, Anabela Miranda - A Determinação da Medida da Pena Privativa de Liberdade: os Critérios da culpa e da Prevenção. Coimbra: Coimbra Editora, 1995, p. 273. 
Neste sentido, já aquela autora ${ }^{48}$ profetizava nos anos noventa, que "a necessidade de uma ligação entre a determinação da medida e execução da pena é de tal forma evidente, que tanto basta para se perceber que a empiria que se desenvolveu no terreno a execução é vital para aquela atividade".

Pelo que o próprio artigo $70 .^{\circ}$ deveria contemplar nesta lógica sequencial, uma alusão expressa às necessidades de (res)socialização que face à prática de certo tipo de crime se impõem. Retirar essa dimensão à determinação da medida concreta da pena é retirar a simbiose que uma e outra fase devem assumir no restabelecimento da paz social e da futura reintegração daquele indivíduo na sociedade.

\section{Conclusões - notas finais}

"Walls are terrible but man is good"

BLOUET $^{49}$

Platão, no seu Protágoras, afirmava o seguinte: "Quando na inflicção das penas se procede acertadamente, o castigo não se applica por causa da falta perpetrada, pois é impossível impedir o mal consummado, mas para obviar a uma falta futura, afim de que o réu não reincida e sirva de exemplo às testemunhas do seu castigo" ${ }^{0}$.

O ponto de partida do legislador penal na modelação jus-valorativa do artigo $40 .^{\circ}$, n. $^{\circ} 1$ repousa no princípio da dignidade da pessoa humana, o qual traz, para o campo da execução da pena, um outro, que postula a manutenção da titularidade dos direitos fundamentais, onde encontra albergue, a teoria da prevenção especial positiva.

É na especial atenção ao cidadão privado da sua liberdade que se encontra o ponto ótimo de análise para justificar a secundarização que tem vindo a ser dada à reintegração do indivíduo na sociedade.

O rumo voraz dos acontecimentos que temos testemunhado, especialmente nas tendências criminógenas, na transnacionalização da fenomenologia do crime e do seu multifacetado e intrincado iter, devem fazer suscitar nos doutrinadores que tipo de prisões queremos e que homens (res)socializados precisa a sociedade. Mas não estará a sociedade ela própria agrilhoada, numa crise identitária? De onde devem partir os ditames axiológicos?

48 Rodrigues, Anabela Miranda - A Determinação da Medida da Pena..., p. 275.

49 Blouet apud FoucAult, Michael - «Complete and Austere Institutions». In: Imprisonment, The International Library of Criminology, Criminal Justice \& Penology, 1999.

50 Castello Branco, António D’Azevedo - Estudos Penitenciarios e Criminaes, Lisboa, 1888. 
De fora para dentro, ou de dentro para fora dos muros? Questões que permanentemente nos assolam e que exigem aturado labor científico para respostas se imponham.

Da sintomatologia registada, e positivada em relatórios e estudos internacionais e internos, verifica-se uma síndrome que poderíamos apelidar de "síndrome de decalque", dado que os muros não conseguem filtrar os fenómenos desviantes, ou, pelo menos, não têm almejado tal desiderato.

Em Portugal todos os dias se vêm multiplicando casos de efetiva transgressão de normas de segurança e da legalidade dentro dos estabelecimentos prisionais, tornando os muros invisíveis para a perpetuação do crime, e deitando por terra qualquer intento para a paralisação do ato criminoso.

Se em face do último relatório sobre o sistema prisional e tutelar de 2017, ressalta a boa intenção em aproximar o direito legislado e sua aplicação efetiva", a verdade é que o estado de coisas, talqualmente fomos descrevendo, entorpece e delapida aquilo que é o fim último da instituição penitenciária - o da reintegração do agente, para que possa voltar à sua vida regular sem a mácula que até ali carregou e sem o intento de voltar a cometer crimes.

Aqui chegados, afigura-se estabelecer um renovado ponto de partida. Para que pontos de chegada sejam construídos e plenamente alcançados.

\section{REFERÊNCIAS BIBLIOGRÁFICAS}

AnCel, Marc - A nova defesa social, Trad. Osvaldo Melo. Rio de Janeiro: Forense, 1979

BecCARIA, Cesare - Dos Delitose das Penas. 2. ${ }^{a}$ Edição. Tradução do italiano Dei Dellitie delle Pene de José de Faria Costa. Lisboa: Fundação Calouste Gulbenkian, 2007.

BITTAR, Eduardo - «A Justiça Kelsiana». In: Revista da Faculdade de Direito da Universidade de São Paulo, 1996. BOAVIDA, Joaquim - A Flexibilização da Prisão. Coimbra: Almedina, 2018.

CAIADO, Nuno - «A Política Criminal para a execução das penas e medidas uma ideia para uma década». In: Revista Julgar, n. ${ }^{\circ} 28,2016$.

Castello Branco, António D’Azevedo - Estudos Penitenciarios e Criminaes. Lisboa, 1888.

CorreiA, Gonçalo da Costa Castanho - A Responsabilidade do Estado pelo processo de ressocialização do Recluso. Dissertação de Mestrado - Orientação Científica do Professor Doutor Mário Aroso de Almeida, Porto, 2016.

Costa Andrade, Manuel da - «Um (novo) Direito Penal para os (novos) Direitos Fundamentais: Aspectos Éticos das pessoas em situação de doença». In: Actas do V Seminário Nacional de Ética para as Ciências da Vida, Lisboa, 1999.

Gomes, Conceição, Duarte, Madalena e Almeida, Jorge, Crimes - «Penas e Reinserção Social: um olhar sobre o caso português». In: Atas dos Ateliers do V Congresso Português de Sociologia, Sociedades Contemporâneas: Reflexividade e Ação, Atelier: Direito, Crimes e Dependências, disponível em https://aps.pt/ wp-content/uploads/2017/08/DPR4628adea6692c_1.pdf.

Kelsen, Hans - Teoria Pura do direito. 6. ${ }^{a}$ Edição. Tradução de João Batista Machado, São Paulo: Martins Fontes, 1998. 
O Intervalo Descompassado entre a vigência e a efetividade da norma- A (Re)emergência da questão ressocializadora INÊS FARINHA

GALILEU - e-ISSN 2184-1845 - Volume XXI - Issue Fascículo $1 \cdot 1^{\text {st }}$ January Janeiro $-30^{\text {th }}$ June Junho 2020 - pp. 142-158

LAmas Leite, André - «Ressocializar, hoje? Entre o “mito” e realidade». In: Revista do Ministério Público, 156, 2018.

FouCAUlT, Michael - «Complete and Austere Institutions». In: Imprisonment, The International Library of Criminology, Criminal Justice \& Penology, 1999.

RAMos, José Joaquim Monteiro - «A dupla perspetiva da norma fundamental em Hans Kelsen». In: Politeia - Estudos Comemorativos dos 30 Anos do Instituto Superior de Ciências Policiais e Segurança Interna e dos 10 anos da Politeia, Volume I, Studia Varia, Ano X-XI-XII, 2013-2014-2015.

RODRIGUES, Anabela Miranda - A Determinação da Medida da Pena Privativa de Liberdade: os Critérios da culpa e da Prevenção. Coimbra: Coimbra Editora, 1995.

Rodrigues, Anabela Miranda - «Política Criminal - Novos Desafios, Velhos Rumos». In: Liber Discipulorum Jorge de Figueiredo Dias. Coimbra: Coimbra Editora, 2003.

Rodrigues, Anabela Miranda - «A Posição Jurídica do Recluso na execução da pena privativa da liberdade». In: Revista do IBCCRIM - Instituto Brasileiro de Ciências Criminais, 1999.

Rodrigues, Anabela Miranda - Novo Olhar Sobre a Questão Penitenciária. 2. ${ }^{a}$ Edição. Coimbra: Coimbra Editora, 2000.

Valente, Manuel Monteiro Guedes - Direito Penal do Inimigo e o Terrorismo. 2. ${ }^{a}$ Edição. Coimbra: Almedina, 2017.

Zaffaroni, Eugenio Raúl - Tratado de Derecho Penal. Parte General - Tomo I. Buenos Aires: Ediar, 1998.

\section{Outras fontes}

Jornal de Notícias: "Festa de arromba de presos na cadeia filmada com telemóveis", publicada a 10.02.2019: https://www.jn.pt/justica/videos/interior/festa-de-arromba-de-presos-na-cadeia-filmada-comtelemoveis-10562686.html

Observador: "Presos recebem contrabando por drones", publicado a 27.02.2019, https://observador.pt/2019/02/27/ presos-recebem-contrabando-por-drones/

Olhar o Futuro para Guiar a Ação Presente - Relatório sobre o Sistema Prisional e Tutelar, Setembro de 2017, disponivel em https://www.portugal.gov.pt/download-ficheiros/ficheiro.aspx?v=29dd78f7-do76-4d80aogb-6b2c94eco9d5

Relatório do Comité para a Prevenção da Tortura e das Penas ou Tratamentos Desumanos e Degradantes, disponivel em https://rm.coe.int/168078e1c8

Relatório do Comité para a Prevenção da Tortura e das Penas ou Tratamentos Desumanos e Degradantes, disponível em https://rm.coe.int/168078e1c8

Site:

http://www.companheiro.org/historial.html 